\title{
Naxal Issues in India Present Trends
}

\author{
Dr. Sanjay Kumar \\ Associate Professor \\ Department of Defence Studies \\ Meerut College, Meerut \\ Email: aridssmeerut2011@gmail.com
}

\begin{abstract}
The present paper seeks to examine the emerging challenges of Naxalism to India's internal security. In doing so, it highlights the origin, causes, and trends of Naxalism. The famous Maoist philosophy that "power grows through the barrel of a gun" is the motivating force for the Naxalites to capture power in India and to do socio-economic justice to the people of tribal areas of the central region which have been neglected ever since the British rule in India. This Naxalite affected area in India is known as "Red Corridor" which spreads from Bihar to Tamil Nadu involving 11 provinces of India and nearly 90 districts of these states. Worst affected states are Bihar, Jharkhand, Chattisgarh, West Bengal, Odisha, Maharashtra, and Andhra Pradesh. However, few districts of M.P, U.P, Assam, Tamil Nadu, and Karnataka are also affected. The Naxalite Movement has some minor influence in Punjab, Haryana and New Delhi also. Despite best efforts, it could not be controlled and found its way in other areas too.
\end{abstract}

Reference to this paper

should be made as follows:

Received: 16.04.2019

Approved: 25.09.2020

\section{Dr. Sanjay Kumar}

Naxal Issues in

India Present Trends

Article No. 18

RJPSS Sept. 2020,

Vol. XLV No. 2,

pp. $148-162$

Online available at:

https://anubooks.com/

rjpss-

2020-vol-xlv-no-2/

https://doi.org/10.31995/

rjpss.2020.v45i01.018 
Naxal Issues in India Present Trends

Dr. Sanjay Kumar

\section{Introduction}

Terrorism as a form of violence and threat of violence to control the people is an idea older than history, but, use of word terror in a present form of political violence goes back only to the French Revo lution of the 1790s. The French revolutionaries were suppressed by the state forces by using terror tactics. Terrorism today is usually associated with political violence perpetrated by independent groups that emerged from within the masses. These unsatisfied non-state groups indulged in political violence are identified by the state machinery as terrorist/insurgent groups.

In comparison with the terror activities of the non-state actors, the statesponsored terrorism was at its peak during the entire period of the first half of the $20^{\text {th }}$ century. In one of his studies, Rummel (1996) estimates that about 170 million people were killed by government forces in the $20^{\text {th }}$ Century, not including 34 million dead in battle. ${ }^{1}$ Most of the people were killed by their state forces to suppress any kind of revolt against the state. History reveals that autocratic leaders like Stalin (42 million), Mao (37million), and Hitler (20 million) were some of the main killers of the $20^{\text {th }}$ century. ${ }^{2}$ Contrary to this, killing by non-state groups is minuscule. According to one of the rough estimates 5 lakh, people were killed in the $20^{\text {th }}$ century by the non-state actors which include people killed by terrorists, insurgents, and guerillas. State-sponsored killing is thus greater by a ratio of about 260 to 1 .

Although the ratio of killing in much smaller, but, it is necessary to identify the major causes which motivate the citizens to use terror tactics against their respective governments in order to achieve political objectives both at local and global levels. Some of the scholars suggested that terrorists are anti-social elements with some kind of psychological disorders and they are socially and morally deficient. They have no hesitation in creating any type of violence in society. Some of them felt those terrorists are basically socially, economically, and culturally deprived frustrating parts of society. Terrorists have required a little dose of political indoctrination to motivate them for adopting terror tactics against the ruling class. They can easily kill and individual or group of people at any time and situation. They are intelligent enough to use modern technology to create terror amongst the masses.

During the later half of the $20^{\text {th }}$ Century, several groups of terrorists emerged at the global level. Most of them are germinated in the economically weak and politically unstable countries. Most of these countries are ill-governed and the majority of their population are ill-treated by the government machineries. India is one of them. It is unfortunate that the partition of the country was done on religious 
RJPSS Sept. 2020 Vol. XLV No.2, ISSN: (P)0258-1701 (e)2454-3403 Impact Factor: 7.717

https://doi.org/10.31995/rjpss.2020.v45i01.018

lines, without taking into consideration its multiple identities, instead of bringing the communal tensions down, in fact, worsened the situation. The two-nation theory created Pakistan, and it still rigorously maintained to survive on this theory. Pakistan finds it difficult to accept the reality that India continues to be a democratic, plural, multi-religious society and that India today has more Muslim citizens than Pakistan. The management of internal security, therefore, assumes great importance. Unfortunately, the rise of contentious politics based on sectarian, ethnic, linguistic, or other divisive criteria, is primarily responsible for the many communal and secessionist movements flourishing in India. The presence of hostile neighbors enables internal conflicts to get external support, which includes money, arms, and sanctuaries. The vested interests exploit these conditions to pursue their own agenda.

Since independence, India has failed to provide the desired impetus, motivation, and dynamism to its main functionaries to think about India and its people. The politico-administrative lethargy has led to the decline of vital institutions of governance. Dreams of our freedom fighters for building a modern industrial society with a strong democratic but centralized state as its pivot has obviously come to an end. The task of creating a common national identity around the core values of democracy, secularism, economic well being, and social justice has failed. The entire country has now been divided into a wide spectrum of localized groups based on caste, ethnicity, language, or religion. If not the paradigm as a whole, at least the state in its intended functions, its role and legitimacy has been put into question. The future seems to hold not only growing inequalities and conflicts, but the geo-political map of South Asia may also even be redrawn ${ }^{3}$.

Consequently, it is very difficult to conceptualize India's security without considering the dynamics of the entire South Asian politics. India's security is influenced by events in South Asia due to historical, geographical, and demographic imperatives. The subcontinent is characterized by extreme diversity in practically every respect. The biggest challenge for the South Asian countries has been the national consolidation into their new identities, which generated its own external and domestic dynamics due to the plural nature of their societies. At the domestic front, in terms of population, they vary from 1 million to more than 1 billion; in per capita income from one of the poorest in the world (Nepal) to the emerging global power (India). Similarly, in the ethnic and cultural aspects: from rather a homogeneous Bangladesh the very heterogeneous India, Nepal, or Sri Lanka. In terms of the ideological foundation of the state, the region comprises from Buddhist Bhutan, Islamic Pakistan, and Hinduism Nepal over semi-secular Sri Lanka to secular India. ${ }^{4}$ In 
Naxal Issues in India Present Trends

Dr. Sanjay Kumar

terms of a system of governance, the region varies from centralized unitary states to federal systems, from Kingdom with substantial royal power, military regimes to multi-party democracies.

South Asia comprises of eight independent states, with over one-sixth of the world's population and numerous ethnic, religious and linguistic groups, is the theatre of ethnic and religious violence which is transnational in its nature and implications. The ethnic, religious, and linguistic overlap has not only affected internal political developments in each state but also inter-state relationships. The boundaries between India and its neighborhoodare easily accessible in some places; therefore social tensions are bound to have a trans-border impact. The uneven economic development in the region along with the traditional linkages of friendship and interaction amongst people have now become has now become a major cause for aiding and abetting subversion, terrorism, and insurgencies all along the Indian borders. The regional geopolitical environment is likely to remain disturbed, which in conjunction with structural political and security confrontations within South $\mathrm{Asia}^{5}$ will continue to influence our internal security. Social tensions particularly in the ethnic and religious field due to its transborder character will continue to be the main areas of exploitation by our traditional adversaries. Muslim fundamentalism and demographic influx are its major manifestations. The need to turn the proximity between South Asian neighbors into a viable economic and security relationship for mutual benefit cannot be overemphasized.

Due to its geographic proximity with the other Asian regions, South Asia is not like other peninsula confined to a region. The Northern ranges link it with the "heartlands" of Central Asia and China, while the Southern Peninsula touches the Indian Ocean and places it in a position to oversee the sea routes from Malacca straits to South Atlantic around the South African rim. In the west, it rests on the Middle East, with which it has historic trade and cultural ties and in the East, it adjoins Yunnan province of China and Myanmar, a natural bridge to South East Asia, with close demographic and cultural ties with India's North East. ${ }^{6}$ India's land borders extend to $15,000 \mathrm{~km}$, the coastline is almost $7700 \mathrm{~km}$ with about 3 million sq.km of the exclusive economic zone (EEZ). India has land borders with seven countries the major ones being, Bangladesh (4096 km), China (3439 km), Pakistan (3325 km), and Myanmar $(1643 \mathrm{~km})$ and maritime borders with five countries. ${ }^{7}$ India has more than 600 islands, which include the Andaman-Nicobar Group in the Bay of Bengal, and the Lakshadweep Islands in the Arabian Sea, some of these island's territories are more than $1300 \mathrm{~km}$ away and are close to the ASEAN region. ${ }^{8}$ 
RJPSS Sept. 2020 Vol. XLV No.2, ISSN: (P)0258-1701 (e)2454-3403 Impact Factor: 7.717

https://doi.org/10.31995/rjpss.2020.v45i01.018

India's security is vulnerable to threats, tensions, and conflicts originating both from domestic and external sources. The analysis of the internal security problems of India should be examined with this background. The independent India inherited a multi-lingual, multi-cultural, multi-religious society. Therefore, our internal security scenario will continue to be complex and varied. While all the problems will intrinsically rest on domestic roots, but, external factors will also play a major role in further aggravating these problems because external forces will easily get the support of dissent forces to exacerbate security concerns. Threats due to terrorism, economic and social disparities, narcotics and drugs, small arms proliferation, voids in energy requirement, and information warfare loom large on the horizon. Maintenance of internal security will thus be one of the biggest challenges facing the country.

During the entire colonial era, Britishers had exploited the weaknesses of society to divide it into communal and religious lines. The basis, on which the partition was conceived and operationalized, was bound to have consequences like those which were witnessed in many parts of the country after independence. Therefore, India was perhaps the first country of its kind, which faced both an external aggression as well as internal disturbances from the day of its birth. Thus, the concept of internal security came into being simultaneous with the birth of this Nation. On the eve of independence, based on the colonial experience, the political leadership of India decided to integrate the fragmented society with grass-root economic development along with nation-building through cultural and social interaction based on secularism, as these linkages were considered durable and stronger rather than political assimilation. Unfortunately, they have failed in both counts.

The biggest challenge before the Indian leadership was to provide a strong and long-lasting notion of a nation after consolidating its territory and people. While they have succeeded largely but there are failures in this regard. The biggest failure of the Indian leadership in the post-independence period was that they have failed to maintain the tempo of the Nationalist feelings amongst its citizens on the level they had generated during the freedom struggle. As a result, in several areas, there is a conflict situation to a point of violence and the contesting groups have become the objectives of security. In simple terms, a sense of insecurity exists between these groups, and the state and terrorism, insurgency, and violence are only its physical symbols. Similarly, issues of ethnonationalism and identity are the outcome of our failure to integrate diverse segments of Indian society. They have also failed to integrate people residing in different regions of independent India as a society closely 
Naxal Issues in India Present Trends

Dr. Sanjay Kumar

bonded with the principle of 'multi-lingual, multi-ethnic, multi-caste and multi-religious society'.

Frustration and anti-nationalist feelings in the various communities of our country are mainly developed due to uneven economic development and unfulfilled aspirations of people, which create a sense of insecurity and deprivation. This may be partially due to bad governance, faulty economic planning, and widespread illiteracy, resulting in what is perceived to be uneven economic well being. If there is just and equitable distribution of economic and developmental benefits people feel satisfied. It is the absence of this satisfaction that drives affected groups to assert themselves and the main target is the government both local and central. In such a state of confrontation, the articulation of group interests in itself results in political exploitation of the communities both by internal and external forces. Since most of such communities are rural and land resource-based, any pressure on the land due to population growth or migration further increases the economic pressure. Educated unemployed further add to the economic and social pressures. The sum total of it is the mobilization of the society in the shape of ethnonationalism?

India's problem of ethnicity, religion, migration, and castes is not new but in the past few decades, these have clearly worsened. This has impacted adversely on the nation and led to a host of new problems. Ethnicity has lately gained a great deal of prominence in the politics of South Asia and this phenomenon is hardly peculiar to India. The "Pakhtoonistan movement" in the Northwest Frontier Province of Pakistan, the "ethnic conflict" in Sri Lanka between the dominant Sinhalese-Buddhist elite and minority Tamils, the "low-intensity ethnic rumblings" between the Drupkas and the Napalese in Bhutan, and Maoist movement in Nepal, are all a part of sub-terrain and ethnic upheavals common to the region which find ethos in India as well.

With the 'Golden Crescent', and the 'Golden Triangle' in India's neighborhood, drug trafficking poses yet another threat to our security. Drug syndicates are generating huge funds, a part of which is being used to give financial support to some of these subversive groups ${ }^{10}$. The intelligence agencies like the ISI are recruiting a number of 'carriers' in drug trafficking as their agents. These agencies provide legal immunity for their criminal activities in their own country in addition to giving them financial and logistical support. Internal security challenges are not confined to any one area, but the North-East, Jammu and Kashmir, and the areas afflicted by Left extremism deserve special mention. 
RJPSS Sept. 2020 Vol. XLV No.2, ISSN: (P)0258-1701 (e)2454-3403 Impact Factor: 7.717

https://doi.org/10.31995/rjpss.2020.v45i01.018

\section{RISE OF NAXALISM IN INDIA}

Maoist (Naxalite) movements have gripped a large part of India and presently pose one of the most serious threats to our internal security. The movement was started and gradually progressed on the imported "ideology" and the "methodology", the basic causes are indigenous. There is a wide-spread perception that the lack of "land reforms" and the methodology of redressal of genuine grievances was the main cause for the poor people to raise their arms against the government. A majority of India's small farmers have still been facing severe economic problems due to various factors, including globalization, credit crunch (compounded by usurious moneylenders), non-inclusive economic progress, etc. In this prevailing situation, it would not be difficult for the Maoists to project themselves as the sole protectors of the poor farmer's interests.

After two decades of India's independence, the Naxalite movement was started from a small village Naxalbari situated at the tri-junction of India, Nepal, and what was then East Pakistan, where tribals took up arms against the oppression of the landlords in 1967. They were forced to use the Maoist tactics of violence to fulfill their dreams and expectations from independent India. The Santhal tribals of Naxalbari, armed with bows and arrows, forcibly occupied the land of the kulaks and plowed them to establish their ownership. They were organized raids against grain holders. In many cases, the entire stocks were lifted and distributed or sold locally at cheaper rates. Between March and May 1967, nearly a hundred incidents were reported to the police. The situation progressively deteriorated. After some dithering, the West Bengal government ordered the police to take action. The movement was squashed, but "Naxal bari exploded many a myth" ${ }^{11}$.

The Naxalites, following Mao's dictum that "if there is to be a revolution, there must be a revolutionary party", formed, on April 22, 1969, the Communist Party of India (Marxist-Leninist). It was declared that "the first and foremost task of our Party is to rouse the peasant masses in the countryside to wage guerilla war, unfold agrarian revolution, build the rural base, use the countryside to encircle the cities and finally to capture the cities and to liberate the whole country"12. The Chinese Communist Party along with the Marxist-Leninist groups of other countries like the UK, Albania, and Sri Lanka welcomed the formation of the CPI(ML) and extended their recognition.

The Maoist philosophy of revolution was based on creating terror by inflicting violence in society. According to the authoritative "Black Book of Communism," an estimated 65 million Chinese died as a result of Mao's repeated, merciless attempts 
Naxal Issues in India Present Trends

Dr. Sanjay Kumar

to create a new "socialist" China. Anyone who got in his way was done away with - by execution, imprisonment or forced famine. The support of Communist China to the Naxalite movement clearly indicates that they will exploit the agony of Indian landless farmers for fomenting violence in India similar to the Chinese great cultural movement.

The Maoist ideology of people's war emphasized the advancement of social and economic life by establishing a classless society through the armed revolution. It was rooted in the anti-imperialist struggle and supported the armed revolution in order to achieve political transformation. Naxalism is actually based on the principles of Maoism to achieve a similar transformation in India. The Naxalite movement was at a peak from about the middle of 1970 to the middle of 1971 with the epicenter at West Bengal. Gradually, it spread into less developed areas of rural central and eastern India, such as Chhattisgarh, Jharkhand, Odisha, and Andhra Pradesh through the activities of underground groups like the Communist Party of India (Maoist). It is estimated that there were a total of about 4,000 incidents in the country from the middle of 1970 to the middle of 1971. The bulk of these was from West Bengal $(3,500)$ followed by Bihar $(220)$ and Andhra Pradesh $(70)$.

Initially, it was viewed as a "higher form of class struggle and the beginning of guerilla war". Naxalite leader Charu Majumdar's assessment was that "every corner of India is like a volcano" about to erupt, that "there is the possibility of a tremendous upsurge in India", and he, therefore, called upon the cadres to start as many points of armed struggle as possible. "expand anywhere and everywhere" was his message. Influenced by the Charu,s assessment, the CPI (Maoist), the major Left Wing Extremist Organization responsible for the expansion of the Naxalite movement in India had started expansion plan at the economically backward areas of entire India as they had organized cadre since 1930, especially in West Bengal area and they had the experience of various mass struggles, most prominently the Tebhanga movement ${ }^{13}$. The movement was further strengthened when the Beijing leadership acknowledged the 'spring-thunder' of 'revolutionary struggle' in the region. Influenced by the communist ideology a large number of unemployed youths were attracted to the Naxalbari Movement. Hundreds of students of the urban areas were also attracted to this movement, who were influenced by the speeches delivered by the Naxal leaders, on the lines of China's Red Guards.

The West Bengal government was surprised by the violent incidents that took place between March and May 1967. With the influx of mass migration from East Pakistan during 1970, the situation was more complicated and required immediate 
RJPSS Sept. 2020 Vol. XLV No.2, ISSN: (P)0258-1701 (e)2454-3403 Impact Factor: 7.717

https://doi.org/10.31995/rjpss.2020.v45i01.018

action. The government had asked the police and army to suppress the movement as early as possible. The Indian government had organized joint operations by the army and the police in the bordering districts of West Bengal, Bihar and Orissa to suppress the Naxalite violence. The operations were conducted between July 1 to August 15, 1971, under code-name 'Operation Steeplechase'. The operational strategy of the Security Forces was to encircle large areas as far as possible and enforce blockade so that no one can either enter or exit. The Army formed the outer ring and the CRPF the inner ring. The local police, which was generally accompanied by a magistrate, carried out a thorough search of the area. Suspected Naxalites were arrested, weapons, ammunition and explosives seized. These operations covered Midnapur, Purulia, Burdwan and Birbhum districts of West Bengal; Singhbhum, Dhanbad and Santhal Parganas of Bihar, and Mayurbhanj of Orissa ${ }^{14}$. The counterinsurgency operations were successfully completed with the arrest of Charu Mazumdar and other leaders by the West Bengal Police in July 1972. A few days later, he died. Charu's death marked the end of the first phase in the Naxalite movement. The period following his death witnessed divisions and fragmentations in the movement.

Although they had succeeded in suppressing the violent movement but the seeds of the Naxalite movement was germinated in the West Bengal along with the other underdeveloped states. With the outside help, it was growing silently in most of the tribal regions of India. The Naxalite movement during the post-Charu Mazumdar was characterized by a number of splits and infighting between some of the major groups. Even Kanu Sanyal, one of the founders of the movement, could not able to maintain unity in several factions. He was forced by the rival groups to give up the path of "dedicated armed struggle" by 1977 and accepted parliamentary practice as a form of revolutionary activity. The infighting between them was started during 1974 when an influential group of the CPI (ML), led by Jauhar (Subrata Dutt), Nagbhushan Pattnaik, and Vinod Mishra, launched a major initiative, with the code name 'course-correction'. This group renamed itself the CPI(M-L) Liberation in1974, and in 1976, during the Emergency, adopted a new line that called for the continuation of armed guerilla struggles along with efforts to form a broad anti-Congress democratic front, consisting even non-communist political parties ${ }^{15}$. The group suggested that instead of conducting pure military armed struggle, there should be greater emphasis on mass peasant political movements based on the Indian zed 
Naxal Issues in India Present Trends

Dr. Sanjay Kumar

version of Marxism-Leninism-Maoism philosophy. They believed that instead of violent protests, political movements will provide a greater impact on government machinery.

During the Janata Government, most of the Naxalite leaders were expecting wide-ranging reforms in the economic policy of India which was semi-feudal in nature and evidenced by several facts such as excessive dependence on agriculture for livelihood, ineffective implementation of land reform laws, the concentration of land ownership in an even smaller number of hands, high rent, eviction of tenants, high rate of interest charged by money lenders and social oppression of scheduled castes which is 'reminiscent of the middle ages'. ${ }^{16}$ But, the new economic policy of India implemented by the newly formed Janata government was not able to transform the basic tenets of the economic policy. They were trying to get the desired results at the cost of the poor. Large tracts of land in the forests and agricultural lands of Chhattisgarh, Jharkhand, Bihar, Andhra Pradesh, etc. were being taken over by the government and given to giant multinationals and national conglomerates for setting up industries or mining activities. This results in forced evictions from lands that are fertile and fruit-bearing for farmers in a predominantly agrarian economy, and hence this eviction not only leaves them landless but also without the means to obtain a steady income and livelihood ${ }^{17}$. Statistics suggest that at least forty percent of the forced evictions in the last sixty years have been of 'Adivasis' to build dams for the country's supply of power and irrigation and for 'development', where the dispossessed never get a share in $\mathrm{it}^{18}$. Due to the lack of effective government policy to provide the basic necessities of life, as promised in the policies, an additional burden was placed by these forceful evictions, which was worked as a catalyst to raise the levels of frustration among the people of these regions.

The second face of Naxalism started taking shape after the reestablishment of Congress's government after the fall of the Janata government. During this period, Pakistan supported terrorism and Chinese indoctrinated Naxalism had got suitable breeding ground in India. The frustrated population had supported these movements to grow. Both these movements had also received operational tactics and required armaments to operationalize these tactical movements from outside India. As a result, their movements were more successful then the countermeasures taken by the Indian government. In November 1995, the People's War Group (PWG) had organized an All India Special Conference in some unknown part of Dandakaranya. The 'Party Programme' as adopted in the Conference reads, "India is a semi-feudal, semicolonial society; here the New Democratic Revolution (NDR) has to be completed victoriously paving the way to the Socialist Revolution and to advance towards the 
RJPSS Sept. 2020 Vol. XLV No.2, ISSN: (P)0258-1701 (e)2454-3403 Impact Factor: 7.717

https://doi.org/10.31995/rjpss.2020.v45i01.018

ultimate goal of Communism. The Indian people are weighed down by three big mountains: feudalism, imperialism, and comprador bureaucrat capital; these are the targets to be overthrown in the present stage of NDR"19.

With the experience of the first phase, the government considered Naxalism to be only a law and order problem and not a social movement, hence, the response was in the form of a counterforce mechanism rather than social security mechanism. This policy was failed and unable to counter the forward movement of Naxalism. In a Status Paper tabled in the Parliament in 2006 by the Planning Commission of India, had suggested security and development strategy for dealing with the "problem of Naxalism'. But, due to the inappropriate attitude and policies of the state governments this strategy had worked as a catalyst for the Naxalism to grow at a much faster pace both in terms of the number of incidents and related deaths. Recent incident of May 25 in which heavily-armed Maoists had ambushed a convoy of Congress leaders in the state's Bastar district, killing several people including state Congress chief Nand Kumar Patel, his son Dinesh, former Union Minister VC Shukla, senior leader Mahendra Karma and ex-MLA Uday Mudliyar and injuring 35 others had forced the government to realize that Naxalism is not only a security-centric problem but it is a social movement also, therefore, to tackle this problem they need a broader strategy both at the micro and macro levels.

\section{Counter Strategy}

As the Naxalism influenced by the Communist ideology, they always reject the parliamentary system of governance and trying to bring about a fundamental change like the existing Indian governance system. For this, they have adopted the strategy of protracted armed struggle through building a base in rural and remote areas and transforming them first into guerrilla zones and then liberated zones, besides area-wise seizures and encirclement of cities and finally, the seizure of political power and achievement of nation-wise victory ${ }^{20}$.

Today around 200 districts in 16 states are experiencing Naxalism related violence. The complexity of the causes of the rise of the Naxalite movement and its implications both for internal and external security required an in-depth understanding of the situation and needs synergy between the central governments and the affected states to successfully tackle this problem. In order to comprehensively deal with this threat, the government has to address its core issues. Socio-economic alienation and dissatisfaction with the widening economic and political inequality will not be solved by military force alone, which seems to be the main instrument employed by the government. The problem required multi-dimensional solutions which include social and economic development, multi-lateral dialogue, and use of force.

The unregulated spread of Naxal related violence indicates that they are getting close cooperation and support of the people. In this context, we need to take 
Naxal Issues in India Present Trends

Dr. Sanjay Kumar

cognizance of what Mao Tse Tung said about Guerrilla fighters. He said, "The Guerrilla is like fish in the ocean and the ocean is like the people's support; the "fish' can survive only so long as there is for them the support of the people". Therefore, it is necessary for the government of India to effectively evolve a policy that can alienate Naxalites from the common men.

Firstly, as the Naxalites are germinated from the marginalized and the poor, a larger percentage of the national budget must be allocated for meeting the requirements of these affected regions. The administration should concentrate on the overall development of these neglected regions through initiatives related to health, education, social welfare, and rural and urban development. Both state and central government must ensure that the initiatives taken for the development of these neglected areas are implemented in true sense. If the socio-economic needs of these marginalized people are addressed seriously, there will be no discontent to fuel the Naxalite's movements and the government will get some success in alienating masses from the movement.

Secondly, the government should initiate sincere efforts for starting a wideranging dialogue with these alienated villagers/tribals, the Naxalites, and state leaders. The popularity of Naxalites with the Adivasis is a reflection of the fact that the government has been unaware or "unapologetically indifferent to their plight". By communicating and starting a dialogue between these stakeholders, the government will be able to alienate common men from Naxalite groups. By opening dialogue, the government can give opportunity for the rebels to join the mainstream by showing them that solutions can be created together with the government, by being part of the political system in a legitimate way. For example, the former director-general of AP concluded that as a result of the ceasefire and dialogue with Maoists in 2004, the violence in the state decreased by $80-90$ percent in the region. ${ }^{21}$

Thirdly, the government is increasingly using force to control the Naxalism. The overdose of use of force is not only forcing them to increase their strength from outside help but also helping them to gain the sympathy of local people as in most of the counter operations several innocent people have also suffered injuries and even died. The excessive use of force also motivated the Naxalites to establish relations with other terrorist groups for getting the latest technologically advanced weapons and other gadgets that are more lethal and advanced than used by the armed forces. 
RJPSS Sept. 2020 Vol. XLV No.2, ISSN: (P)0258-1701 (e)2454-3403 Impact Factor: 7.717

https://doi.org/10.31995/rjpss.2020.v45i01.018

The unchecked growing Naxalite insurgency also reflects a flaw in the federal structure. It clearly reflects that the central government is unable to implement a coherent national strategy to address the threat. The central government has the overall responsibility of mobilizing development, but it cannot do so without the support of the states. The central government and the states need to cooperate together to solve the internal security threats and coordinate the implementation of this multi-dimensional approach. Both organizations must complement and support each other's initiatives and strategies.

Some recently announced relief measures, including the "revolutionary" farm loan waiver scheme, are very welcome steps, but they should be the beginning and not the end of the many measures necessary to retrieve the poor farmers from the potential embrace of the Maoists. The perception of imbalanced subsidies, which is also a major source of alienation, needs to be overcome by introducing a more rational system.

To conclude, the Naxalite problem reflects underlying issues in the Indian social, economic, and political institutions which threaten to expose India to even more danger from outside forces. While the Naxalite movement is mainly an internal threat, with globalization, external and internal security threats are inextricably linked. The complex and multi-faceted approach to solving the Naxalite issue also reflects the fact that this is the biggest menace to India's security in the future.

\section{References}

1. Rummel, R.J., Death by Government, Transaction Publishers, New Brunswick, N.J., 1996, p-38.

2. Stout, C.E. (ed.), Psychology of Terrorism: Coping with the Continuing Threat, Pentagon Press, New Delhi, 2010, p-34.

3. Neelsen, John P., \& Malik, Deepak, "South Asia- Social Fragmentation and Political Crisis in the Periphery" in "Crisis of State and Nation" edited by Neelsen, John P., \& Malik, Deepak, Manohar, New Delhi, 2007, p-9.

4. Ibid, $\mathrm{p}-12$.

5. G.S. Bhargwa, India Security in 1980's - Adelphi Paper No 125, London IISS, 1976.

6. Gupta, Anirudha,'Issues in South Asia : Geopolitics or Geoeconomics", International Studies,34/1, Sage

7. Publications, New Delhi/Thousand Oaks-London, 1997. 
Naxal Issues in India Present Trends

Dr. Sanjay Kumar

8. Ministry of Defence Report, GOI, 2006-07.

9. Bhonsle, Rahul K., "Securing India: Assessment of Defence and Security Capabilities", Vij Books, New Delhi, 2009. p-11.

10. Nair, V.K., "India's Internal Security Compulsions" in "India-2025", Centre for Policy Research, New Delhi, 2000.

11. Marwah, Ved, India's Internal Security Challenges, Strategic Analysis, Vol.27, No.4, 2003 p-1.

12. Singh, Prakash, Naxalite Movement in India, www.geocities.ws/ prakashsavitri1959/NAXAL.docý, visited on 9/6/13.

13. Ibid.

14. Donner, H., Significance of Naxalbari, Occasional Paper, Centre of South Asian Studies, Cambridge University, 2004, p-3.

15. Singh, Prakash, Naxalite Movement in India, www.geocities.ws/ prakashsavitri1959/NAXAL.docý, visited on 9/6/13.

16. Kujur, R., Naxalite Movement in India: A Profile, IPCS Research Papers, 2008, $\mathrm{p}-3$

17. Dasgupta, B., The Naxalite Movement, Allied Publishers, New Delhi, 1974, p116.

18. Vohra, P. \& and Buxy, S., Mariginalization Violence: The Story of Naxalism in India, International Journal of Criminal justice Sciences, Vol. 6, No1\&2, JanDecember, 2011, p-359.

19. Planning Commission of India. (2008). Development Challenges in Extremist AffectedAreas. Retrieved on January 10, 2012, fromhttp:// planningcommission.nic.in/reports/publications/rep_dce.pdf

20. Kujur, R., op.cit, f.n.-15, p-9.

21. Ibid, p-13

22. Carbon, A., Naxalism - The Biggest Security Threat to India, University of Canterbury, New Zealand,http://www.indiafutureofchange.com/ featureEssay_D0012.htm, visited on June 30, 2013. 